\title{
DIAGNOSING PERFORMANCE IN GOVERNING UTILIZATION OF FOREST PRODUCTION IN FMU MERANTI-MUSI BANYUASIN, SOUTH SUMATRA
}

\author{
Ja Posman Napitu ${ }^{* 1}$, Aceng Hidayat ${ }^{2}$, Sambas Basuni and Sofyan Sjaf ${ }^{4}$ \\ ${ }^{1}$ Directorate General of Sustainable Production Forest Management, Ministry of Environment and Forestry \\ ${ }^{2}$ Department of Resource and Environmental Economics, Faculty of Economics and Management, \\ Bogor Agricultural University, Indonesia \\ ${ }^{3}$ Department of Forest Conservation and Ecotourism, Faculty of Forestry, \\ Bogor Agricultural University, Indonesia \\ ${ }^{4}$ Department of Communication and Community Development, Faculty Human Ecology, \\ Bogor Agricultural University, Indonesia
}

Received: 4 October 2017, Revised: 1 February 2019, Accepted: 29 April 2019

\begin{abstract}
DIAGNOSING PERFORMANCE IN GOVERNING UTILIZATION OF FOREST PRODUCTION IN FMU MERANTI -MUSI BANYUASIN, SOUTH SUMATRA. Perspective differences of users related to forest area utilization has caused tenurial conflicts, as well as, possible utilization conflicts. This study aimed to understand stakeholders' interests and influences as exogenous factors that caused the non-optimal institutional performance. This study used an institutional diagnostic approach to understand how the situation and action arena is from inter-influencing institutional entities. Data collection used the convergent parallel mixed method (CPMM) approach, while analysis used the rapid land tenure assessment (RaTA) method. Further, this study used the Institutional Analysis Development (IAD) method to explain how the exogenous factors influence each other. The results show that the characteristics of biophysical attributes, community attributes, as well as, rule in use were inter-influencing within the action arena. Besides, based on the post-prospective analysis result, policy decision opted by the government tend to not consider the community's existence, who have been using the land for their livelihood. This situation has caused utilization conflicts between communities and concession holders. Thus, this study recommends: 1) the stakeholders to establish a communication forum for all parties to obtain clear information about forest utilization and to support institutional performance; 2) institutionalizing local community to govern forest utilization, and 3) determining management and concept of sustainable forest, as well as, policy making.
\end{abstract}

Keywords: Institutional diagnosis, exogenous factor, policy effectiveness, outcome

DIAGNOSIS KINERJA PENGATUR PEMANFAATAN HUTAN PRODUKSI DI KPHP MERANTI - MUSI BANYUASIN, SUMATERA SELATAN. Perbedaan sudut pandang dan pemabaman pengguna dalam memanfaatkan kawasan butan menyebabkan tumpang tindib areal dan berpotensi menimbulkan konflik pemanfaatan. Penelitian ini bertujuan untuk mengetabui kepentingan dan pengaruh para pihak sebagai faktor eksogen yang berdampak tidak optimalnya kinerja kelembagaan. Diagnosis kelembagaan digunakan untuk mengetabui bagaimana arena aksi dan situasi aksi dari entitas kelembagaan saling mempengarubi. Data dikumpulkan dengan menggunakan pendekatan convergent parallel mixed method (CPMM) dan langka kerja analisis menggunakan rapid land tenure assessment (RaTA). Untuk. menjelaskan bagaimana faktor eksogen saling mempengarubi digunakan Institutional Analysis Development (LAD). Hasil penelitian menunjuk.kan babwa karakteristik atribut biofisik, atribut komunitas, dan rule in use saling mempengarubi dalam situasi arena aksi. Selain itu, dari post-prospective analysis menjelaskan bahwa piliban kebijakan cenderung tidak mempertimbangkan keberadaan masyarakat yang telah menggunakan lahan untuk. penghidupan mereka. Kondisi ini menyebabkan terjadinya konflik pemanfaatan antara masyarakat dan pemilik i₹in. Rekomendasi penelitian: 1) untuk membuat forum komunikasi bagi semua pihak untuk mendapatkan informasi yang jelas tentang pengguna hutan dan mendukung kinerja; 2) perlu pelembagaan masyarakat lokal dalam pengaturan pemanfaatan, dan 3) penentuan pengelolaan dan konsep kelestarian butan dalam pembuatan kebijakan.

Kata kunci: diagnosa kelembagaan, faktor eksogen, efektifitas kebijakan, hasil

*Corresponding author: njpnapitu@gmail.com 


\section{INTRODUCTION}

Forest provides great benefits to people, but the destruction of forest threatens human life and other beings, (Daily, et al. 1999; Colfer, Sheil, Kaimowitz, \& Kishi, 2006; Chakravarty, Ghosh, Suresh, Dey, \& Shukla, 2012). Deforestation and degradation occur in Indonesia, it cannot be denied, are partly due to poor forest management system during the Right of Forest Concession/HPH-era and illegal logging activities (Kartodihardjo, 1998; Holmes, 2002; Pilgrim, Cullen, Smith, \& Pretty, 2007).

Approximately, in 1950 Indonesia's total forest area was 159 Mha (Million hectares), but decreased to 91 Mha in 2015. Oil palm and rubber plantations, cropping areas, as well as, settlements are the most causing factors to deforestation and degradation (FAO, 2015; Tsujino, Yumoto, Kitamura, Djamaluddin, \& Darnaedi, 2016). So, the change may occur due to forestry sector and non-forestry sector activities.

Further, changes occur in forest area are due to permits granted for the industrial forest plantation (IFP), ecosystem restoration (ER), community plantation forest $(\mathrm{CPF})$, village forest $(\mathrm{VF})$, and community forest (CF). While, in the non-forestry sector, deforestations are generally caused by the Forest Area Utilization Permit (FAUP - Izin Pinjam Pakai Kawasan Hutan $(\mathrm{IPPKH})$ ) including mining, infrastructures, non-procedural plantation, and transmigration area. Therefore, these permits for, both forestry and non-forestry, within the forest area are potentially causing utilization conflicts due to area overlapping (Gamin, Nugroho, Kartodihardjo, Kolopaking, \& Boer, 2014). Economic motives among dwellers are also thought to pose problems in forest management (Tsujino, Yumoto, Kitamura, Djamaluddin, \& Darnaedi, 2016).

The above-mentioned issues have become critical topics in almost every forestry-related meeting. Several actions and programs to countermeasure the issue from the government side are:

a. The development of Sustainable Forest Management program (SFM/PHPL), as well as, Community-Based Forest Management (CBFM), by the Ministry of Environment and Forestry (MoEF), such as: communal plantation forest (CPF/HTR), community forest $(\mathrm{CF} / \mathrm{HKm})$, and forest village $(\mathrm{FV})$. See Table 1 for targets and accomplishments of the aforementioned government programs.

b. The execution of Indonesia's Forestry Congress VI, with the theme "Reposition of Indonesia's Forestry towards Good Governance".

c. Establishing site level management area, such as the Production Forest Management Units (PFMU/KPHP).

There are five causal linkages, which threaten forest management, i.e.: a) irresponsible concession permissions for corporations (Kartodihardjo, 1998), b) lack of science and experts (Kartodihardjo, 2013b), c) governmental alignments to private concession

Table 1. Target and realization

\begin{tabular}{lccc}
\hline \multicolumn{1}{c}{ Permit } & $\begin{array}{c}\text { Target Hectare } \\
\text { Unit }\end{array}$ & RealizationHectare & $\%$ \\
\hline CPFP/HTR & 734,397 & 19,270 & $26.59^{*}$ \\
CF/HKm & 328,452 & 94,372 & $28.73^{*}$ \\
FV/HD & 318,024 & 67,737 & $21.29^{*}$ \\
IFP-SFM & 234 & 76 & $32.47^{* *}$ \\
IFP-SFM & 296 & 107 & $36.15^{* *}$ \\
\hline
\end{tabular}

Source: *PSKL (2015) **KAMH (2013) 
holders (Suhendang, 2013), d) corruption, collusion, and nepotism activities (Hermosilla \& Fay, 2005; Tacconi, 2007; Kartodiharjo, 2016), and e) lack of active participation from communities to support MoEF targets related with forest management (Gulbrandsen, 2004). Thus, it can be said, that continuous conflict of utilization and unstable management are a form of policy failure (Kartodihardjo, 2013). Also, conflicts due to unaccepted extension of concession permit by the communities are a form of bad governance (Sheil \& Wunder, 2002; Larson \& Ribot, 2007).

Mostly, conflicts are caused by lack of proper social interaction, which resulting in poor institutional performance in forest management (Ostrom 2010; Ostrom \& Basurto, 2011). In this case, different perspectives among the involved stakeholders about the cause of conflicts are able to change and affecting their interactions. This can be seen when people who use forests for their livelihoods are not permitted to do so by the government, while licenses are granted to outside companies in the same locations instead (Tucker, 1999; Kartodihardjo, 2013). Even, people who seek for their livelihood within the forest area tend to be perceived as having illegal activities by the government, but not the companies, that are used to destroy forests (Tacconi, 2007).

In this regard, the Meranti FMU, based on the results of their operational assessment, was categorized as to having sufficient category. This is because, they still lack support organizationally, either from village communities, or having an insufficient role from surrounding stakeholders due to community roles have no institutionalization (Hendartin, Nugroho, \& Kartodihardjo, 2011). Institutionalization itself is related with the determination of: management form, rules of utilization, as well as, who use the forest area. These factors are causing the institutional performance to be inoptimal, cannot be separated from the exogenous factors (Suwarno, Kartodihardjo, Kolopaking, \& Soedomo, 2015), which influence each other, such as: a) attributes of biophysical characteristics of natural resources; b) community attributes (community, government and private/business owners), and c) regulation used (Elinor. Ostrom \& Hess, 2007; Ostrom, Gardner, \& Walker, 1994). Frequently, all of those three attributes might lead to competition on various transformation patterns, both management and mutual claims of land (Dolšak \& Ostrom, 2003; Tucker, \& Ostrom, 2005; Fleischman et al., 2014).

Institutional diagnosis was carried out to explain communities' role as part of the communal forest management attributes (Larson \& Ribot, 2007). Then, the analysis results of exogenous factors were used to explain: a) the correlation of the exogenous factors from community attributes to the action arena, as well as situation of the action (Sunderlin et al., 2005), b) how various attributes of the community factors could affect rules, that are determining the outcomes (Jagger, Luckert, Duchelle, Lund, \& Sunderlin, 2014), and c) position and roles of each participant in using information, as well as how is their interaction, that affect other actors (Ostrom, 1990; Andersson, 2004; Cantiani, 2012). The outcomes of this research are defined as the policy decision choice of each party. Clear information were needed to determine, whether to choose the choice of the parties or to change the rules (Suwarno, 2014). In this case, the required information includes; a) exogenous factors; b) costs incurred, and c) expected benefits (Agrawal, 2001).

Based on the above description, this research was conducted to answer three main questioned problems, as follows: 1) what factors influence the institutional performance of forest area utilization arrangement? 2) Institutionally how to strengthen government's position within such utilization arrangements? 3) How would be the form of communities' role surrounding the concession area to legitimize governmentbacked permissions for corporations? Formulations to the above problems were the basis of why this research is significant 


\section{MATERIAL AND METHOD}

This research was conducted in the Meranti FMU, and aimed to explain how exogenous factors are inter-influencing each other. This study was carried out by diagnosing institutional regulatory frameworks using Institutional Analysis and Development (IAD) method (Ostrom \& Hess, 2007).

The convergent parallel mixed method (CPMM) (Creswell, 2013) was used to collect all data, namely: land change, literature study, history and map of changes. This study also used in-depth interviews of 123 key informants, consisted of 97 people from 8 observed villages, 4 MoEF officials, 8 District Forestry Service officials, 4 Provincial Forestry Service officials, 5 staffs of the Technical Implementation Unit of the MoEF, and 5 managers from concession holders in the forestry sector. Other additional informants were obtained by the snowballing method. This study used the Rapid Land Tenure Assessment (RaTA) method for data analysis (RaTA) (Galudra et al., 2010).

\section{RESULT AND DISCUSSION}

Exogenous factors affect each other in the arena of action of the interests of the parties (Ostrom, 2005); (Ostrom, Gardner \& Walker, 2006). Based on the diagnostic, the institutional framework performance in Meranti FMU are: a) biophysical characteristic attributes, b) community attribute, c) rule in use, d) action and situation arena, e) outcome, and f) evaluation criteria.

\section{A. Characteristic of Biophysical Attribute}

The Meranti FMU consists of three regulated forest types, i.e.: fixed production forest/HPT area $53.36 \%$, Production forest/ HP area $38.68 \%$ and Protected forest/HL area $7.96 \%$. There are two types of utilization types for non-protected forests i.e.: a) allowed for forest wood product utilization, such as Industrial Forest Plantation/IFP Communal Forest Plantation/CFP, Community Forest/CF, and Forest Village/FV; b) PAUF (Izin Pinjam Pakai Kawasan Hutan - IPPKH), such as for mining, infrastructure, or transmigration areas.

There are various biophysical characteristic attribute within the FMU area. This consists of renewable resources, such as: timber forest product, non- timber forest product, oil palm, rubber plantation, rice fields, etc.; as well as non-renewable resources, i.e.: oil, coal, and tinlead. All of those resources greatly influence the choice among users, which is largely determined by their interactions, which might be in the form of intervention to policy-making processes, since it is susceptible to clouts from those who have financial powers (Maryudi et al., 2018). The latter actors could also be influenced by other institutional factors for using resources in forest area, such as: political environment, regulatory and legal environment, economic- and technological environment (Dolšak \& Ostrom, 2003). Talking about other biophysical attributes, there are various land covers in the study location. Secondary forest, which mostly consists of ecosystem restoration

Table 2. Forest land cover

\begin{tabular}{lrr}
\hline Land Cover & Area & \multicolumn{1}{c}{$\%$} \\
\hline Secondary forests & $95,999.55$ & 39.32 \\
Planted forests & $69,085.07$ & 28.29 \\
Plantation & $13,002.93$ & 5.33 \\
Shrubs & $29,898.14$ & 12.25 \\
Mixed farming & $35,948.14$ & 14.72 \\
Mining & 107.07 & 0.04 \\
Settlement & 121.43 & 0.05 \\
\hline Total & $244,162.33$ & 100 \\
\hline
\end{tabular}

Source: KPHP Meranti (2015) 


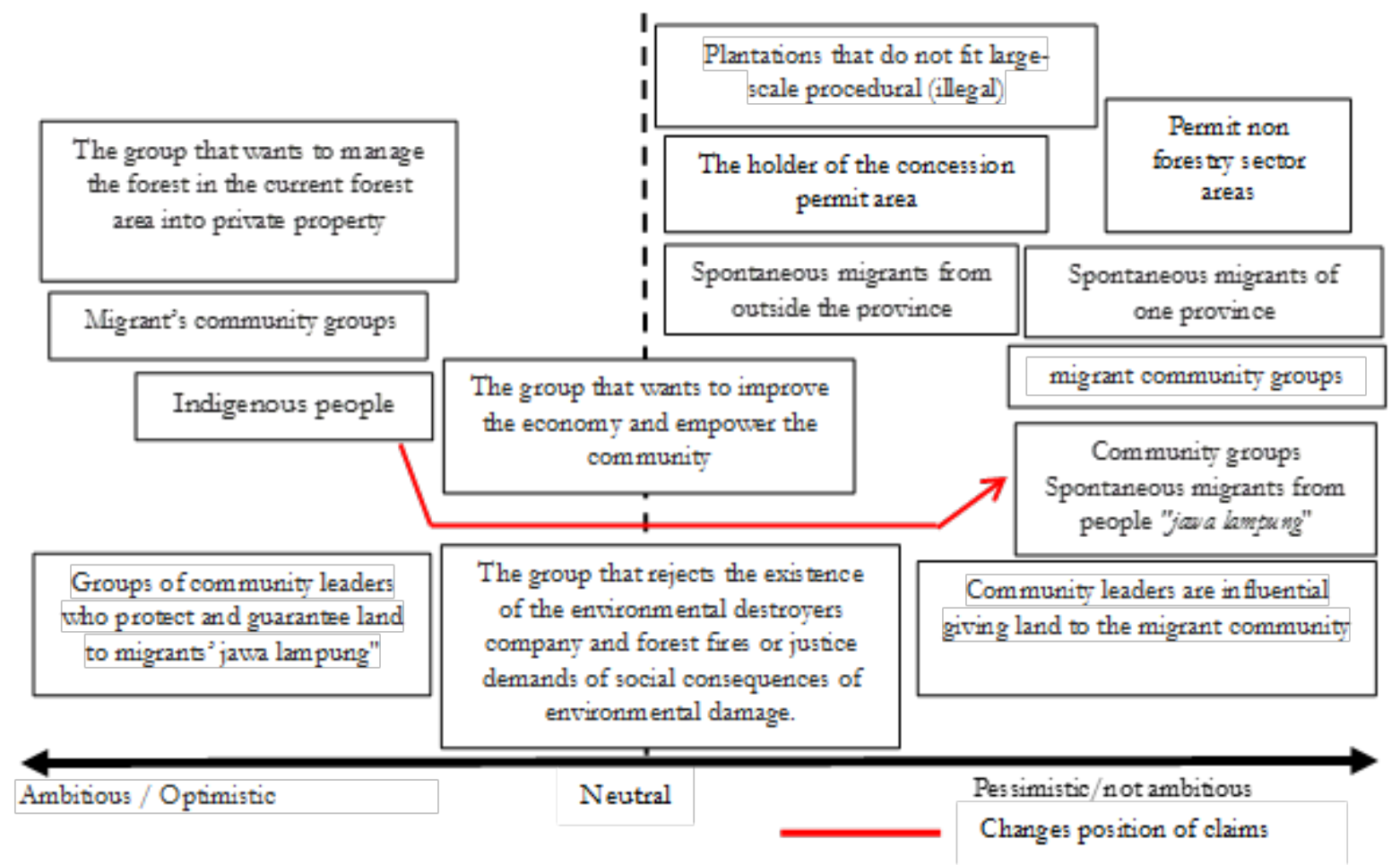

Figure 2. The change of community position on land claim

(ER) and protected forest area, are covering $39.32 \%$ of the land. Meanwhile, there is also $28.29 \%$ planted forest, which was originally primary forest during the forest production rights era (FPR - bak pengusabaan butan ( $\mathrm{HPH})$ ). Details of various land covers are shown in Table 2, meanwhile see Table 3 for the detailed utilization-based area; including claimed, overlapping area by the community.

\section{B. Characteristics of Communities}

Decision making in action situations could be influenced by collective choices of institutional communities, although it might lead to ineffective regulation, due to different interests (Agrawal \& Ostrom, 2001). Analysis of community attributes is important to identify roles of each participant, whether to influence or be influenced by policy outcomes (Mwangi \& Markelova, 2009).

There are key factors to analyze community attributes, i.e.: behaviors, level of understanding, homogeneity level, the size of composition and inequality of assets (Suwarno, 2014). Community groups in the Meranti
FMU were classified by their origin, as follows: a) indigenous, b) migrants, c) spontaneous migrants of the same province, d) spontaneous migrants from other provinces, e) spontaneous migrants of "Java-Lampung" people. The aforementioned classification is illustrated in Figure 2.

The results found three types of claim orientation by the community, as follows: a) rights claimers, those who wanted to manage land by acquiring current forest area into private property, b) socio-economic oriented group, those who wanted to improve their economy and empower community, c) environmentconcerned group that rejects the existence of corporation, which damaging environment and causing forest fires. The latter group also demands justice for social impacts from environmental damages they experience. There exist several characteristic-based communities, such as: a) those whose cultural values concur with government-made policies; b) Those who are capital owners and influenced by knowledge, and c) those who reject current policies. 
Table 3. Predicted community land claims and biophysical condition

\begin{tabular}{lcl}
\hline \multicolumn{1}{c}{ Land cover } & $\begin{array}{c}\text { Predicted area } \\
\text { (hectares) }\end{array}$ & Biophysical condition \\
\hline FMU Meranti areas (community occupation and non-permit areas/wilayah tertentu) \\
\hline Community Forest & $9,848.51$ & Mixed plantation/Kayu Komersil Rimba Campuran (KKRC) \\
Planted forests & 788.45 & Acacia Mangium, Eucalyptus, and Jabon \\
Plantation & $9,581.01$ & Oil palm aged 7-15 years, Rubber \\
Shrub/farm & $5,396.80$ & Types of savannah and KKRC diameter <30 cm \\
Agricultural land mixture & $9,843.80$ & Rubber, oil palm, and coffee plantations, cocoa, fruits. \\
Mining & 30.95 & Oil and petroleum \\
Settlements & 121.43 & Public building, houses, government offices, road facilities \\
\hline Sum & $35,610.95$ & \\
\hline Industrial Forest Plantation /IFP area & \\
\hline Plantation estate, community & $55.933,88$ & Plantation estate, shrubs, rubber, oil palm about 3-5-years old, \\
plantation, and Settlement & & Rubber age about 10-15 years and settlement \\
\hline Restoration ecosystem area & & \\
\hline Rubber plantation, Settlement & $2.500,01$ & Rubber plantation (age: 10-15 years) \\
\hline Total overlapping areas & $94.044,84$ & \\
\hline
\end{tabular}

Source: Processed primary data (2016) and Strategic Plan FMU Meranti 2013-2014 (2013)

This study also observed five types of community claiming intention toward current utilization and management policies, i.e.: a) ambitious, who have strong desire to take over forest area and shifting status quo; b) neutral, those who submissive to policy changes c) nonambitious, those who do not have desire to claim forest area; d) optimistic, those who think they are able to do the claim, and e) pessimistic, those who do not think they are able to win their claim. Often, different interests might also change the above intentions, from nonambitious to ambitious, or vice versa.

The above-mentioned claiming intentions were observed within the transmigrant community, which has splitting standpoints about programs run by the Meranti FMU. Some people within this community are ambitious. These people, though most of it is indigenous, reject spontaneous Lampung migrants, who illegally occupied an area to establish village. They, also intend to claim some of the forest area as communal plantation forest (CPF hutan tanaman rakyat (HTR)). The rest are non-ambitious, who think they need counsels and socializations from government.

\section{Rule in Use}

The rule in use could be seen from how each party is able to use and obtain benefits from forest area. Further, this is explainable from the existence of two access mechanisms, i.e.: structure-relation of access mechanism, and rights-based access mechanism (Ribot \& Peluso, 2003). In this study, working rules were visible from: effective rules, related to forest and land utilization, within communities; as well as, government policies related to regulated forest utilization. Land ownership occurs with various processes over time. Community rules among indigenous people have been ruling for generations, which are distinguishable from five forms of access mechanism (Table 4).

Forest utilization is regulated under the Law No. 41/1999 about Forestry, which direct the government as forest resource manager for the sake of public welfare as generally stated within the $33^{\text {rd }}$ Article of 1945 Constitution. This is, since forest has great potential, not only from its timber, non-timber products and biodiversity, but also from the underlying soil containing oil and minerals. 
Table 4. Access mechanism for community land use

\begin{tabular}{|c|c|c|}
\hline Form of access & Community origin & Rules/norms \\
\hline $\begin{array}{l}\text { 1. Hom-steading, shelter or stay } \\
\text { (home) }\end{array}$ & $\begin{array}{l}\text { Indigenous people } \\
\text { (Kubu people) }\end{array}$ & $\begin{array}{l}\text { Land for livelihood, hunting, home- } \\
\text { steading }\end{array}$ \\
\hline 2. Para rimbo & Musi people & $\begin{array}{l}\text { Rubber/mixed estates are in patron- } \\
\text { client relationship among Pesirah and } \\
\text { indigenous people. }\end{array}$ \\
\hline 3. Shifting cultivation & Musi/ Komering Tribe & $\begin{array}{l}\text { Shifting cultivation for crops/dryland } \\
\text { farming arrangements (cycles) to } \\
\text { maintain soil fertilization. }\end{array}$ \\
\hline $\begin{array}{l}\text { 4. Community core plantation/ } \\
\text { PIR or smallholder }\end{array}$ & $\begin{array}{l}\text { A spontaneous migrant from } \\
\text { Musi people, Komering people, } \\
\text { Rupit people, and Rawas people, } \\
\text { and from Java people) }\end{array}$ & $\begin{array}{l}\text { Oil palm plantation is obtained by } \\
\text { trading with the figure/village head }\end{array}$ \\
\hline $\begin{array}{l}\text { 5. Illegal transmigration area } \\
\text { (village establishment without } \\
\text { proper license from authority) }\end{array}$ & $\begin{array}{l}\text { Often said: Jawa Lampung } \\
\text { Migrant from Lampung }\end{array}$ & $\begin{array}{l}\text { Managing open access land ex-IFP } \\
\text { obtained by buy-selling from leader } \\
\text { persons of villages }\end{array}$ \\
\hline
\end{tabular}

Source: Processed primary data (2016)

Further, utilization within the production forest area is not only for forestry-related industries, such as industrial forest plantation (IFP - butan tanaman industri (HTI)) but also for non-forestry sectors. Due to globally spreading demand, those particular areas are also licensed for non-forestry sectors, i.e.: coal and oil mining, even for infrastructural purposes as regulated in Law-Replacement Government Regulation (LRGP - Peraturan Pemerintah Pengganti Undang-Undang (Perpu)) No. 61/2012 about Mining Activities within Forest Area. The above complexity is also because of the abundant amount of permissions a licensee can hold. Such license, forest area utilization permission (FAUP - izin pinjam pakai kawasan butan (IPPKH)), is granting several permissions to its holders: exploration activities, wood production, as well as, mining for non-mineral materials. Based on the Directorate General of Planology report, in 2012 licenses were issued for 971.825 ha mining area and 258 units of buildings within forest area, which increased to $820.294,34$ ha and 238 building units for the same purpose in 2013.

The aforementioned situation clearly shows how a complex license granting for forest area utilization, in this context, could cause area overlapping and other difficulties. In this situation, a powerful user, in pursuing its interest, can influence the decision-making process, which might result in both poor organizational performances, as well as policy issues (Dann 1994; Kartodihardjo 2008). In accordance with the above complicacy, this study has also observed policy shift, where previous policy decision (SQ1) was overlapped with newer policy decision (SQ2) (see Figure 3). This case is visible from 704 ha of concession grant for coal mining (based on license no.: 336/ Menhut-II/2012) on the CFD area, which was previously validated by license no.: 249 /Menhut-II/2009 (see Table 4 and 5 for reference). The above example indicates the involvement of game-changing information, whether from internal or external sources, to policymakers, which affect the policy outcome. This is, since policymakers often choose subjectively the economic benefits rather than ecological awareness in the game arena (see Figure 3).

\section{Action and Situation Arena}

Arena situations within the action arena, which are confined in institutional framework, affect information and transaction costs to 


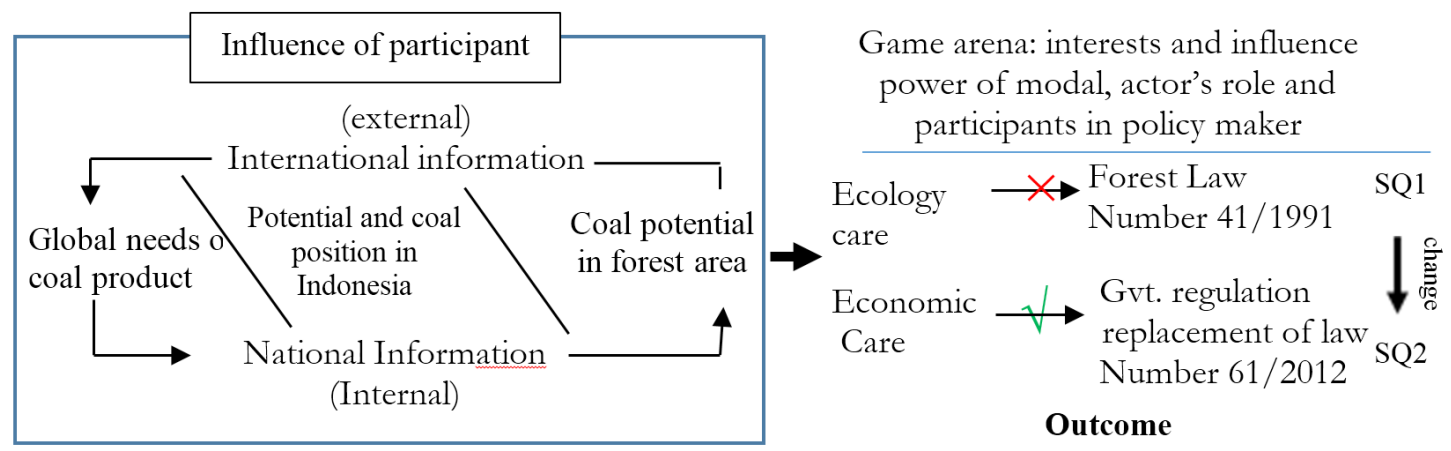

Remark: $\sqrt{ }=$ Decision choices (changed) (SQ2) $X=$ the previous decision (lost) (SQ1) $\quad S Q=$ Status Quo

Figure 3. Rules in using the change process (SQ1 $\rightarrow$ SQ2)

participants. Thus, this might also impact policy choice situation, which often leads to land utilization change and overlapping, as well as, conflicts.

\section{Information and transaction costs}

Information significantly determines how policymakers choose their decision, whether to grant or refuse, permit proposals. Applied consideration might vary, from the type of venture, produced goods, or extracted materials; which also includes potential impacts on environment and economic-related values. Not only for the policymakers, information is also required by venture owners, including IFP, to understand current market condition, i.e.: product prices, production costs, as well as, global market updates. Further, from the available information participants could gain knowledge about decision making factors, such as: market perception and political transaction costs (Kartodihardjo, 2008). Moreover, during the application process, negotiating ability might limit the needs of both sides, such as: proposed area, location, and potential products.

Once a business thought to be feasible, the next possible decision is about how to increase production, which is going to involve, both biophysical and community characteristics, in the form of interaction among parties. Often, such interactions cause high transaction costs for corporations during decision-making process due to the existence of overlapping area (Kartodihardjo, Nurrochmat, \& Justianto, 2015). The amount of the significant transaction costs would depend on key policymakers, whether beneficial or not for them, and often ignoring community interests. The abovementioned case was well explained by one of the informants, as follow:

"Indeed, sometimes we have to understand (the policymakers' intentions) too if we do not understand and are not sensitive to such (intentions)...., we would never know when our permission will come out. The amount of the cost depends on his position. Indeed, in this society, it can be arranged" -

\section{Maman LH (67) IFP Manager-}

The action arena could be more complicated if interests of local elites and their politics are involved. This is, since during local elections - as candidates eager to gain more fund to cover their campaign costs, such transactional activities are increasing. While at the same time concession holders sense the necessary to get closer to bureaucratic administration for the sake of their interests. This means, that structural power could affect corruption events (Baseowi et al., 2012), as described by the source:

'The company is obliged to 'donate', because 'be' is, the former head of the sub-district here. He knows companies here and the village head is his subordinate. (Thus) if we do not 'donate', we cannot work in this area."

-Heri (54) IFP manager- 


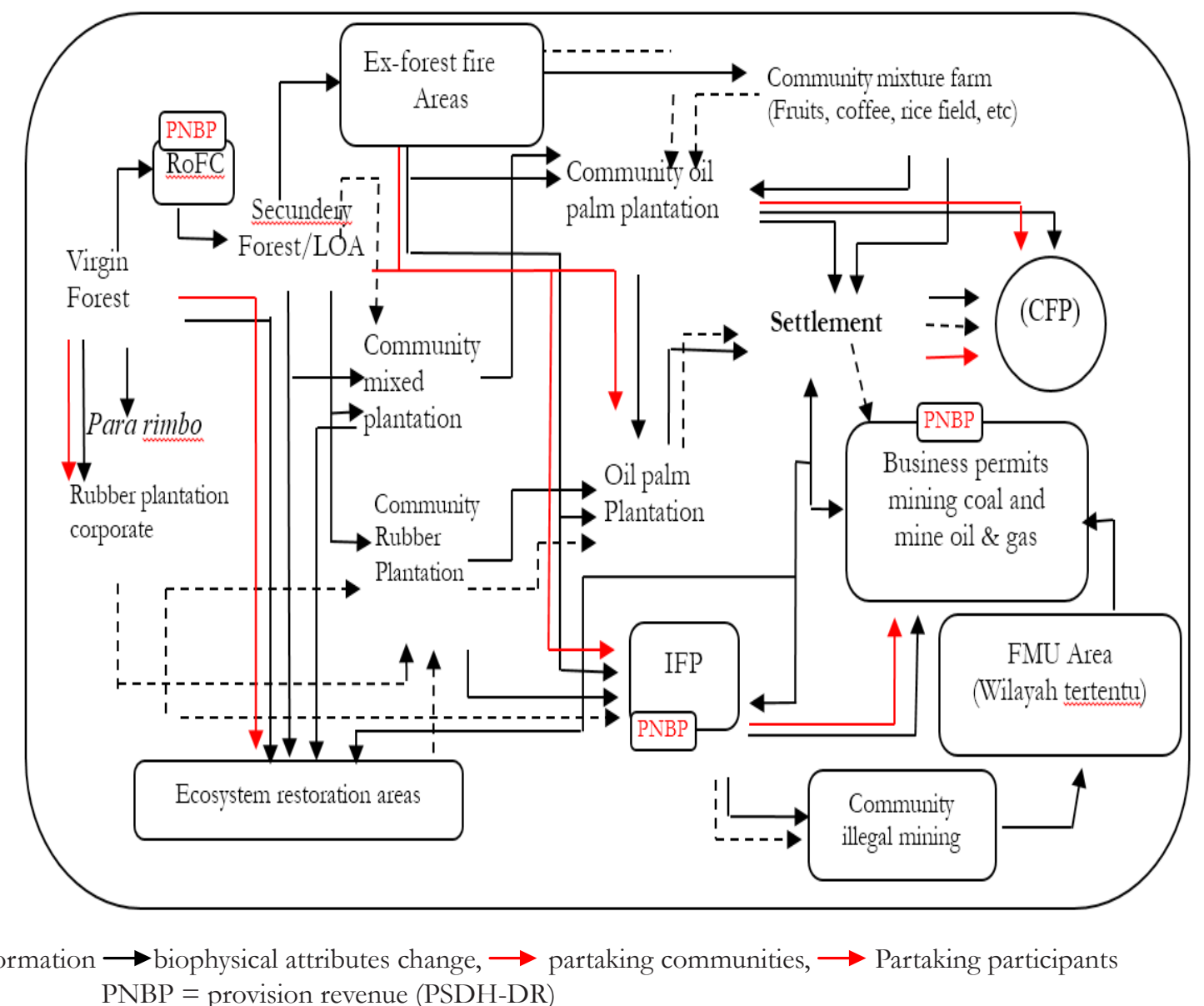

Figure 4. Changing process of biophysical characteristics of forest areas

There is a gap between management objectives and the implementation of forestry regulations, due to such kind of interactions between corporate individuals and policymakers (Suwarno, 2014). Thus, any sanctions imposed to private forestry sector for their non-compliant activities against regulations are also influenced by corruption practices (Hidayat, 2007). However, to do research about the aforementioned corruptive interaction is difficult, even for corporate HRD, due to its high sensitivity, as well as, possible cover ups. Such transaction cost, which in the above context is bribery, in the action arena involve local officials and companies, whether legal or not, as well as other users (Nurtjahjawilasa. Kartodihardjo, Nurrochmat, \& Justianto, 2015). Further, this also shows that the Meranti FMU is lacking optimal performance supports from all parties.

\section{Overlap and take over areas}

It is common for forestry officials, either from central ministry or local services, to perceive that land used by local people within the forest area is a law transgression. This is, since these officials often ignore communities surrounding forest area as part of the environment from socio-cultural interactions and processes. Their livelihood activities within forest area are seen as to only having economic motive. Meanwhile, policymakers often grant concession licenses on community area, although it could potentially cause access overlapping and tenurial conflicts. Such problems could occur because kinds of misguided activities, i.e.: a) permission granting to one or more new users on a currently utilized area; b) revocation of permission extension, which leads to open access area and gather free loaders, and c) permission granting on cropped customary area. 


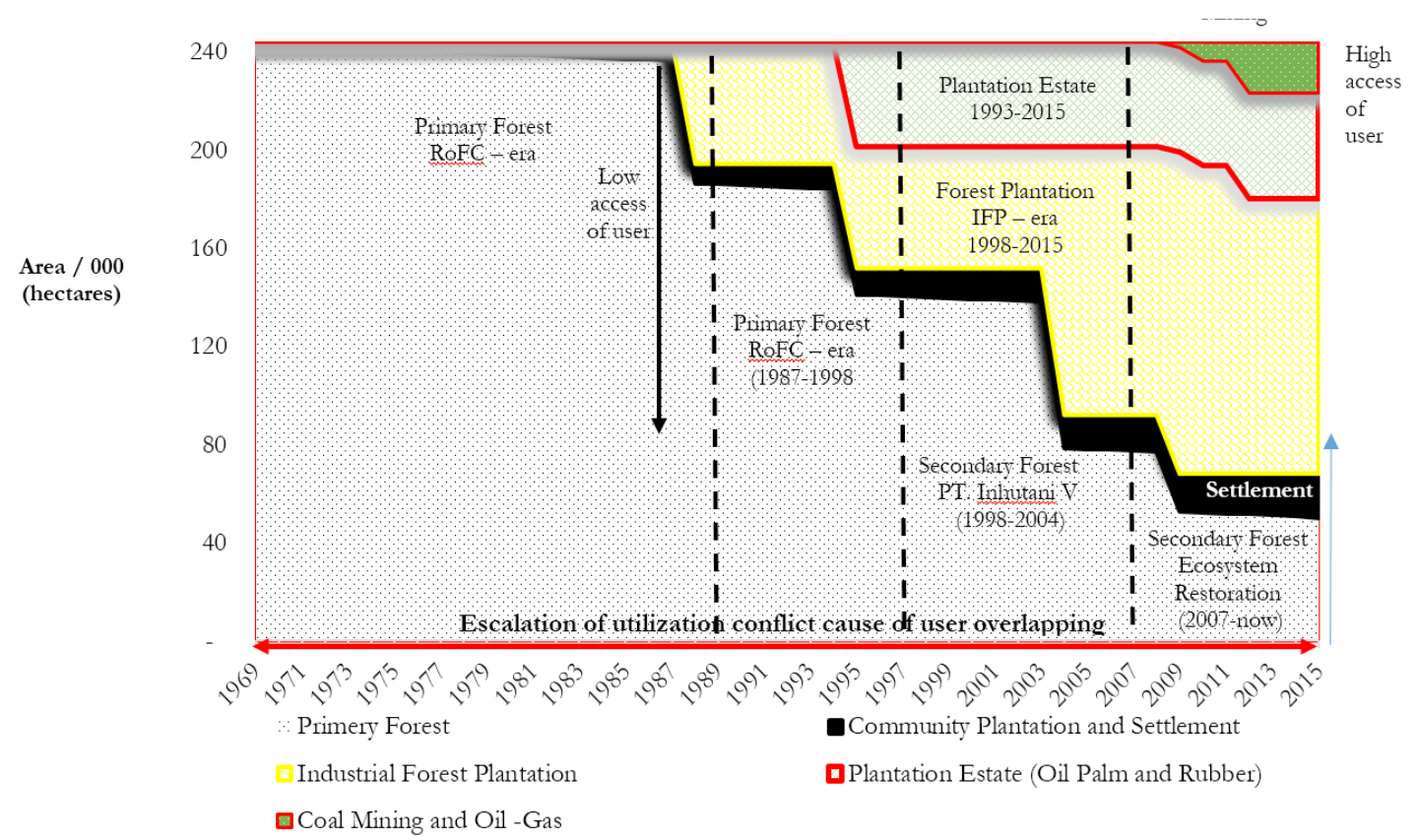

Figure 5. User change of position and transformation utilization conflict

The existence of diverse biophysical conditions and dynamic user changes lead to complex interactions of exogenous factors within the action arena. Biophysical changes and user interests in the action situation determine the outcomes, which are desirable for, both actors and participants, when the decision maker agrees upon their choice (See Figure 4 for the processes of the aforementioned biophysical attributes changes).

Further, such interactions might also lead to policy interventions, which could be caused by: a) presence of new land users; b) biophysical changes of the area; c) user dynamics; d) addition to the community attributes, and e) 'rule to use' changes. In the Meranti FMU, the above case was observed from the land use change history, where the previous FPR area were altered to IFP due to policy shifts, while some of the latter area were eventually occupied by groups of people, and were conflicting. Then, decision was remade for the occupied area, from the previously IFP to CPF, to muffle the conflicts. Initially, the establishment of the FMU in Indonesia was influenced by discourses of policy de-concentration among the policymakers (Ekawati, 2013). So, it is an ineffective policy decision if the implemented policy, in this case the FMU establishment, does not improve institutional performance (Kartodihardjo, 2008; Budiningsih, Ekawati, Gamin, Sylviani, Suryandari, \& Salaka, 2015). Even, policy decision, in this case permit issuance, without community recognition, would lead to conflicts in forest area, which is so-called as 'legal but not legitimate permission' (Sinabutar, Nugroho, Kartodihardjo, \& Darusman, 2015). The changes of forest area was started since 1969. It referred to permits of Minister Decree and regional regulation (Table 5 and Table 6) as shown in Figure 5.

\section{E. Outcome}

The results of, both dynamic interactions and complicating situations, within the forest area of the Meranti FMU are: 1) land use access lost for local people, and 2) existing users emigration from forest area. At the end, such complicacies in forest area lead to utilization conflicts of each user (Wibowo, Race, \& Curtis, 2013). Further, the aforementioned complexities are only for the sake of licenses, which are categorized into two, forestry and non-forestry sectors, as follows: 
Table 5. Forestry Sector Permits

\begin{tabular}{lccrr}
\hline \multicolumn{1}{c}{ User } & $\begin{array}{c}\text { Basic decision } \\
\text { (Outcome) }\end{array}$ & $\begin{array}{c}\text { MoF determined } \\
\text { area } \\
\text { (Hectares) }\end{array}$ & $\begin{array}{c}\text { Area of Meranti } \\
\text { FMU } \\
\text { (Hectares) }\end{array}$ & $\%$ \\
\hline REKI (Primary forest) & 293/Menhut-I1/2007 & $52,170.00$ & $50,153.00$ & 20.55 \\
BPP - I (IPF) & 337/Menhut-II/2004 & $59,345.00$ & $38,187.00$ & 15.65 \\
BPP -II (IPF) & $79 /$ Kpts-II/2009 & $24,050.00$ & $24,283.00$ & 9.95 \\
RHM (IPF) & $90 /$ Menhut-II/2007 & $67,100.00$ & $12,131.00$ & 4.97 \\
SBB (IPF) & 249/ Menhut-II/2009 & $55,055.00$ & $53,639.00$ & 21.98 \\
WAM (IPF) & 252/Menhut-II/2009 & $6,290.00$ & $6,547.00$ & 2.68 \\
Eks Pakerin (IPF) & 226/Kpts-II/1998 & $43,380.00$ & $23,375.00$ & 9.58 \\
Samhutani (IPF) & 86/Kpts-II/1999 & 58.88 & 58.88 & 0.02 \\
FMU areas concession & 689/Menhut-II/2012 & $35,641.00$ & $35,641.00$ & 14.61 \\
\hline Total & & $343,089.88$ & $244,014.88$ & 100 \\
\hline
\end{tabular}

\section{Forestry sector}

Permittance issued for forestry sector are regulated in the Minister of Forestry (MoF) Decree No. P.31/Menhut-II/2014. Total area for forestry sector is $343,089.88$ ha, while $244,014.88$ ha of it is in the Meranti FMU. See Table 5 for the detail.

\section{Non-forestry sector}

Permittance issued for non-forestry sector within the forest area, in the form of FAUP license, which are regulated under several decrees, i.e.: 1) MoEF Decree No. 50/Mlhk/ Sekjen/Kum-1/6/2016 Jo; 2) MoF Decree No. 65/Menhut-II/2013 jis, and 3) MoF Decree No.: 43/Menhut-II/2008. Until April 2015, total area of this category was $5,653.07$ ha (see Table 6).

\section{F. Evaluation Criteria}

In evaluation criteria, institutional effectiveness based on the aforementioned regulations of forest area utilization, against various interventions, was visible from how parties intervene the regulatory body. The successful policy choices are about how the solving problems are.

Criteria for the institutional evaluation in the Meranti FMU, with an objective management approach, were based on the Government Regulation No. 3/2007 Jo. No. 6/2008, as follows: a) social impacts of current policy decisions; b) economical contribution from, both forestry and non-forestry sectors; c) the amount of labors work in both sectors, community empowerment, and conflicts; d) impact of the currently applied policies to SFM objectives. Those criteria were analyzed by post-prospective analyses.

1. Impact of policy failure

The policy outcomes, such as overlapping area, are perceived by land users as institutional obstacles. Meanwhile, the community's rights of authority are seen as an institutionally endogenous problem rather than institutional exogenous factor. As there are land claims from some of the users to others, which violate their rights, it shows the existence of policy failures that fail to solve the main problems (Kartodihardjo, 2008). The above conflicting land claims have led to forest destructions and are complained by local people, as said by one of them below:

"The production forest area of the Meranti group that was formerly managed by the logging company (FPR) Asia-log Co. and Padeca Co., was later replaced by Niti Remaja Co., before subsequently replaced by state-owned company Inbutani $V$., but the FPR activities actually were causing to forest destruction. And now, to use the remaining timbers, the government gave permission to IFP (bolders). (We have been experiencing) forest degradation, frequent forest fires, as well as, scarce fresh water. We, indigenous people here, would like to 
Table 6. Non-Forestry Sector Permits (until April 2015)

\begin{tabular}{|c|c|c|c|c|}
\hline User & Basic decision (Outcome) & $\begin{array}{c}\text { Area } \\
\text { (hectare) }\end{array}$ & $\begin{array}{l}\text { Type(s) of } \\
\text { forest } \\
\text { function }\end{array}$ & Activity/Product \\
\hline PT. MAL (1) & SK. 423/Menhut-II/2011 & 505.17 & $\mathrm{HP}$ & Coal mining \\
\hline PT. MRB & SK. 101/Menhut-II/2014 & 691.05 & HP & Coal mining \\
\hline PT. GSM & SK. 862/Menhut-II/2013 & 353.70 & HPK & Tin foil mining \\
\hline PT. NIP & SK. 331/Menhut-II/2012 & 99.90 & HP & Coal mining \\
\hline PT. BM & SK. 466/Menhut-II/2012 & 616.71 & HPK & Coal mining \\
\hline PT. KPS & SK. 864/Menhut-II/2014 & $1,532.96$ & HPТ & Coal mining \\
\hline PT. TM. & SK.740/Menhut-II/2011 & 354.90 & HPK & Coal mining \\
\hline CP Co. (1) & SK. 29/Menhut-II/2012 & 75.88 & HPT & Oil-Gas mining \\
\hline CP Co. (2) & SK. 140/Menhut-II/2014 & 30.33 & HP & Pipeline \\
\hline CP Co. (3) & SK. 158/Menhut-II/2014 & 212.59 & HL,HPT,HP & Petroleum \\
\hline СР Co. (4) & SK. 133/Menhut-II/2013 & 13.70 & $\mathrm{HP}$ & Petroleum \\
\hline PT. MI & SK. 185/Menhut-II/2012 & 19.02 & $\mathrm{HPK}$ & Road coalmine \\
\hline PT. MAL (2) & SK. 267/Menhut-II/2012 & 10.10 & $\mathrm{HP}$ & Port of coal \\
\hline PT. DSSP P & SK. 480/Menhut-II/2013 & 46.80 & НР,HРК & Electric Power \\
\hline PT. SBB & SK. 336/Menhut-II/2012 & 704.00 & $\mathrm{HP}$ & Port \\
\hline PT. JOB P. & SK. 460/Menhut-II/2009 & 248.53 & $\mathrm{HP}$ & Pipeline \\
\hline PT. CP (5) & SK. 561/Menhut-II/2013 & 48.59 & HL,HPT,HP & Road \\
\hline PT. CP (6) & SK. 561/Menhut-II/2013 & 92.73 & $\mathrm{HP}$ & Pipeline \\
\hline PLN (electric power) & SK. 800/Menhut-II/2014 & $2,335.00$ & HP,HPK & Sutet $275 \mathrm{kv}$ \\
\hline PT. PU & 71/Kpts-II/92 & $3,100.00$ & HPK & Rubber plantation \\
\hline PTPN VII & $\begin{array}{l}584 / \mathrm{Kpts} / \mathrm{I} / 2007 \\
\text { (governor decree) }\end{array}$ & $16,800.00$ & APL/HPK & Oil palm plantation \\
\hline PT.BSS & $\begin{array}{l}\text { 01/SK-IL/MUBA/1998 } \\
\text { (Badan Pertanahan } \\
\text { Nasional/BPN) }\end{array}$ & $11,000.00$ & APL/HP & Oil palm plantation \\
\hline
\end{tabular}

Source: BPKH Region II Palembang (2015), Forest Service South Sumatera (2012) (unpublished)

Information: $\mathrm{HP}=$ production forest, $\mathrm{HPK}=$ conversion production forest, $\mathrm{HPT}=$ fixed production forest

ask "what exactly is the forestry service doing?"

Iskandar (54)

Community leader of Sako Suban Village

The above statement represents similar experience of others within the study location: a poor long-term forest development concept, while its short-term goals have only economic orientation, which are depleting the resources. The point is, that the concept Indonesia have, in regards of forest management, is unsustainable, where we would have to pay the costs of such forest degradation in the future.

In fact, such precedence has been proven by the poor current situation in the Meranti FMU, i.e.: 1) smaller secondary forest area $(52,170 \mathrm{ha})$ compared to production forest area $( \pm 339,000$ ha); 2) decreasing incomes due to natural resource lost, and 3) high forest rehabilitation costs due to ecological destruction. Aside of forest damages, however, the corporation of the provides jobs and community empowerment activities.

\section{Economic contributions}

A realistic approach to assess the evaluation criteria can be seen in non-tax government revenues (NTGR - penerimaan negara bukan pajak (PNBP)) from the forestry sector. The above NTGR-based institutional performance assessment could provide national cash flows and transaction costs from forestry sector, 
Table 7. Share acceptance from the FRP-FR

\begin{tabular}{lrr}
\hline Year & $\begin{array}{r}\text { Musi Banyuasin } \\
\text { (Million rupiahs) }\end{array}$ & $\begin{array}{r}\text { South Sumatera } \\
\text { (Million rupiahs) }\end{array}$ \\
\hline 2008 & $49,793.91$ & $52,661.60$ \\
2009 & $98,248.89$ & $104,175.22$ \\
2010 & $41,934.39$ & $50,451.47$ \\
2011 & $117,227.58$ & $185,266.28$ \\
2012 & $32,256.45$ & $156,040.48$ \\
2013 & $12,324.75$ & $42,890.22$ \\
2014 & $10,078.42$ & $20,708.13$ \\
2015 & $8,263.62$ & $28,752.82$ \\
\hline
\end{tabular}

Source: Primary data analysis from personal discussion about NTGR with the MoEF (2008-2015) (Unpublished)

whether decreasing, steady, or increasing; which is also depicting the effectiveness of policy decisions. This, since the disappearance of transaction costs means, that the government has succeeded to control illegal activities, so thus institutional goals are achievable (Ostrom 2005).

Statistically, there are depleting amounts of NTGR in Musi Banyuasin Regency, since 2012. However, the values are contrasting with the total NTGR of Palembang Province, which increases due to higher tax imposed, in the form of forest value replacement fund (FVRF pengganti nilai tegakan (PNT)), on FAUP licenses, particularly for coal mining in Lahat and Muara Enim Regency (Table 7).

Further, Indonesia also have fund compounding mechanisms for environmental impacts from forestry area: reforestation fund (FR - dana reboisasi (DR)) and forest resources provision (FRP - provisi sumberdaya butan (PSDH)). These are regulated in the Government Regulation No. 92/1999 jo. No. 59/1998; and the Decree of Forestry Minister No.: 18/Menhut -II/2007.

\section{Performance organization}

Policy choice evaluation to the Meranti FMU establishment was conducted to observe what impacts and how are their managerial performances at site level. This study also observed the outcome of regulations to evaluate the institutional dynamic of the action and situation of arena, which mainly related to the decentralization - a policy, that governs the authority delegation of central government to its lower structure, either institutions or local governments. However, such policy might lead to forest degradation, if it is uncontrolled (Gregersen, Contreras-Hermosilla, White, \& Phillips, 2005).

The FMUs, as at-the-site management units have a reciprocal relationship between biophysical attributes, community characteristics, and community rules of forest utilization. Meanwhile, the evaluation criteria, in this study, were used for observing the interaction of each parties in acquiring the utilization area. Moreover, with certain rules of the game, it is possible for the parties to intervene and change the outcomes, as well as, position of the role of Meranti FMU.

Furthermore, FMUs establishment as part of the working unit of local staff (WULS - Satuan kerja perangkat daerah (SKPD) management to support local governments was a form of policy choice. Thus, the evaluation criteria for the performance assessment were taken from the 2015-2024 Mid-Term Forest Management Plan (MTFMP - rencana pengelolaan butan jangka menengah (RPHJM)), as follows: 1) synched and implementation outcomes of planned, budgeted activities; 2) workloads; 3) human resources availability; 4) technical barriers, as 
Table 8. Comparison of plans and its realizations of FMU strategic programs in forestry sector year 20152016

\begin{tabular}{|c|c|c|c|}
\hline Kind(s) of Activity & Activity Breakdowns(s) Based on Budgeted Plans & 2015 & 2016 \\
\hline \multicolumn{4}{|c|}{ 1. Carry out of forest management } \\
\hline \multirow{5}{*}{$\begin{array}{l}\text { a. Forest governance and } \\
\text { management }\end{array}$} & Addition of Facilities and Infrastructure & In-list & In-list \\
\hline & \multicolumn{3}{|l|}{ Arranging the Short-Term Forest Management Plan (STFMP) } \\
\hline & STFMP 2015 & In-list & - \\
\hline & STFMP 2016 & In-list & - \\
\hline & STFMP 2017 & In-list & In-list \\
\hline b. Forest utilization & Unplanned & - & \\
\hline c. Forest use area & Unplanned & - & \\
\hline \multirow{2}{*}{$\begin{array}{l}\text { d. Rehabilitation and } \\
\text { reclamation }\end{array}$} & Forest and land rehabilitation & (n lis) & 4 \\
\hline & Forest and land rehabilitation improvement & & unlisted \\
\hline \multirow{4}{*}{$\begin{array}{l}\text { e. Forest Protection and } \\
\text { forest conservation }\end{array}$} & Forest area reservation and protection & In list & In list \\
\hline & Forest fires control & In list & In list \\
\hline & Potential conflicts \& resolution identification in FMUs & In list & $y$ \\
\hline & Improving Potency Identification of FMUs & - & unlisted \\
\hline \multicolumn{4}{|c|}{ 2. Implementation of forest policy } \\
\hline & Unplanned & - & - \\
\hline \multicolumn{4}{|c|}{ 3. Implementation of Forest Planning, Organization, Control, and Protection } \\
\hline & Potency Identification for the entire FMU area & (n list) & 1 \\
\hline & Improving Potency Identification of FMUs & - & unlisted \\
\hline \multicolumn{4}{|c|}{ 4. Protection and assessment implementation in forest management } \\
\hline & Improving forest management protection techniques & In list & In list \\
\hline & $\begin{array}{l}\text { Forest protection, safety, control, \& management } \\
\text { techniques }\end{array}$ & In list & In list \\
\hline \multicolumn{4}{|c|}{ 5. Investing and collaboration funds management for the FMUs area utilization } \\
\hline & Business plan arrangement of the FMUs & In list & - \\
\hline & Business plan improvement for the FMUs & & unlisted \\
\hline
\end{tabular}

Source: Budgeted programs implementation list (DIPA) 2015-2016 (Unpublished)

well as 5) operational obstacles. Based on the observation, previously budgeted activities were unbudgeted in the next year, i.e. community development (see Table 8).

In 2015 the results of the analysis of performance evaluation criteria in the Meranti FMU for the budgeted programs implementation list (BPIL - daftar isian pelaksanaan anggaran (DIPA)) were: a) incompatible activities and implementation with the results of field observation; b) costs inefficiency from non-revisable budgets of incompatible projects in the Meranti FMU, since the budgets are arranged by the Controlling and Utilization Office of Production Forest
(CUOPF - Balai Pemantanan dan Pemanfaatan Hutan Produksi (BPPHP)); c) no budgets arranged for community empowerment and participation, as well as, capacity building, that are important for conflict resolution, and d) Discontinuous business development activities ,as well as, agreement with communities related to conflict identification and resolution, which caused negative perceptions among communities about the Meranti FMU performance.

Related with the aforementioned situation, there are several influencing factors of the Meranti FMU program, whether implementable or not according to the BPIL, i.e.: 1) prerequisite- 

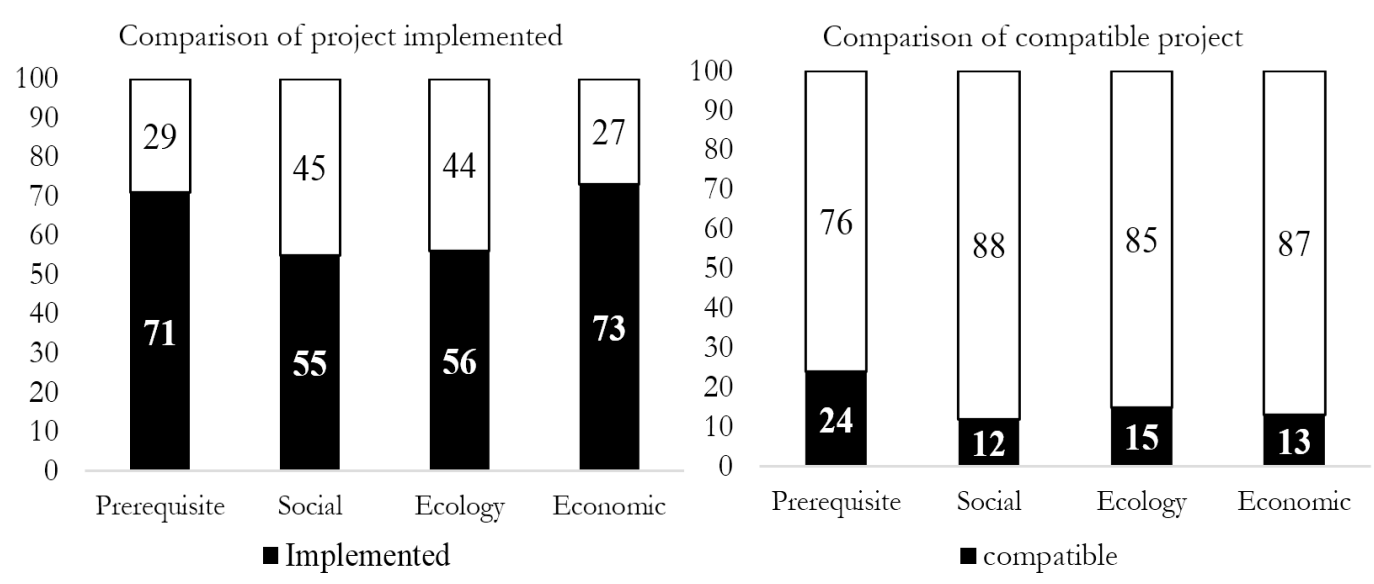

Figure 6. Comparison realization implemented and compatible of project based on DIPA 2015-2016 and RPHPJP 2013-2024

related aspects (71\%); 2) social (55\%); 3) ecological (56\%), and 4) economic (73\%).

However, based on the observation, such programs have lack of, both compatibility and implication, to the community needs. The implementation scores for each aspect are, as follows: 1) $24 \%$ for prerequisite-related aspect; 2) $12 \%$ for social; 3) $15 \%$ for ecological, and 4) $13 \%$ for economic (see Figure 6).

The above results show, that many of the budget spending activities carried out by the Meranti FMU are just a business as usual, e.g.: meetings, official travels, as well as, performanceunrelated procurements for infrastructures. This, also show, that the business as usual activities, done by the Meranti FMU, are only to establish their existence and legitimacy from communities with the license issuing authority they have, which is contrasting with the policy outcome from the fact, that there are tenurial conflicts due to land utilization overlapping problems.

\section{CONCLUSION AND RECOMMENDATION}

\section{a. Conclusion}

The result showed that the institutional diagnosis of forest utilization arrangements in the Meranti FMU is strongly influenced by interests of parties, which has caused overlapping utilization. Uncontrolled interests of the parties and overlapping utilization is an indication of a non-optimal institutional performance. There are several correlating elements for institutional, i.e.: the characteristics of biophysical attributes; community attributes, and influential rules in use within the action arena, which altogether form a game changing complex interaction pattern based on possible outcomes of user interests. We also found, that the government chooses to neglect the existing user, particularly the indigenous people as the owners of rights authority.

Further, the policymakers used to their lawbacked authorities for every license issuance without gaining legitimisation from available stakeholders, which displays policy failures due to the existence of corrupting activities among capital owners and government individuals. Such situations lead to: 1) ineffective policy implementation; 2) forest degradation from the tragedy of the commons situation; 3) decreasing NTGR income; 4) utilization conflicts, and 5) imbalance in cash flows between planned budgets and revenues.

The study also found, that there are changes of policy outcome, which tend to ignore biophysical conditions and surrounding communities. Such outcomes are strongly influenced by internal information, which are 
provided by influential parties. Moreover, the policy decisions often consider only shortterm economic motives, which in fact lead to environmental degradation and tenurial conflicts among users.

\section{b. Recommendation}

a. To create communication forums for all parties to receive clear information about forest utilization and to support institutional performance of forest area management

b. Institutionalization the role of community in the utilization arrangements.

c. Community activities that have been facilitated by the granting of management licenses and arrangements adapted to the concept of forest sustainability.

d. Policy-maker should take the community and biophysical conditions of the forest area in regulation.

\section{ACKNOWLEDGEMENT}

Thanks to the Meranti FMU in Musi Banyuasin, South Sumatera, village chiefs in the study site, as well as, the Centre of Education and Training for Human Resource of the Ministry of Environmental and Forestry.

\section{REFERENCES}

Agrawal, A. (2001). Common property institutions and sustainable governance of resources. World Development, 29(10), 1649-1672. doi://10.1016/S0305-750X(01)00063-8.

Andersson, K. P. (2004). Who talks with whom? The role of repeated interactions in decentralized forest governance. World Development, 32(2), 233-249. doi://10.1016/j. worlddev.2003.07.007.

Budiningsih, K., Ekawati, S., Gamin, Sylviani, Suryandari, E.Y., \& Salaka, F. (2015). Tipologi dan strategi pengembangan Kesatuan Pengelolaan Hutan di Indonesia. Jurnal Analisis Kebijakan Kebutanan, 13(1), 283-298.

Cantiani, M. (2012). Forest planning and public participation: A possible methodological approach. iForest - Biogeosciences and Forestry, 5(2), 72-82. doi.10.3832/ifor0602-009.
Chakravarty, S., Ghosh, S., Suresh, C., Dey, A., \& Shukla, G. (2012). Deforestation: Causes, effects and control strategies. In Okia, C.A. (Ed.), Global Perspectives on Sustainable Forest Management (pp. 3-28). Rijeka, Croatia: Intechopen. doi.10.5772/2634

Colfer, CJP. Sheil, D. Kaimowitz D., \& Kishi, M. (2006). Forest and human health in the tropics: Some important connections. Unasylva, 57(224), 20-23.

Creswell, J. W. (2013). Research design: Qualitative, quantitative, and mixed methods approaches. research design qualitative quantitative and mixed methods approaches (4 ${ }^{\text {th }}$ ed.). Los Angeles. USA, London. UK: SAGE. doi://10.1007/s13398014-0173-7.2

Daily, Getchen C. Alexander, Susan. Ehrlich, Paul R. Goulder, Larry. Lubchenco, Jane. Matson, Pamela A. Monney, Harold A. Postel, Sandra. Schneider, Stephen H. Tillman, David. Woodwell, G. M. (1999). Ecosystem services: Benefits supplied to human societies by natural ecosystems. Issues in Ecology, 4(4), 1-12. doi.1092-8987.

Dolšak, N., \& Ostrom, E. (2003). The commons in the new millennium: Challenges and adaptation. (Nives Dolsak dan Elinor Ostrom, Ed.), Politics, science, and the environment. London, England: The MIT Press. doi://10.1007/s11077-0052857-5.

Ekawati, S. (2013). Evaluasi implementasi kebijakan desentralisasi pengelolaan hutan produksi. Journal of Forestry Policy Analysis, 10(3), 187202.

FAO. (2015). Global forest resources assessment 2015 Desk reference. (Report). Rome. doi.10.1002/2014GB005021

Fleischman, F. D., Loken, B., Garcia-Lopez, G. A., \& Villamayor-Tomas, S. (2014). Evaluating the utility of common-pool resource theory for understanding forest governance and outcomes in Indonesia between 1965 - 2012. International Journal of the Commons, 8(2), 304336.

Galudra, G., Sirait, M., Pasya, G., Fay, C., Suyanto, Noordwijk, M. van, \& Pradhan, U. (2010). RaTA : A Rapid land tenure assessment manual for identifying the nature of land tenure conflicts. Bogor, Indonesia: World Agroforestry Centre.

Gamin, G., Nugroho, B. Kartodihardjo, H., Kolopaking, L.M. \& Boer, R. (2014). 
Menyelesaikan konflik penguasaan kawasan hutan melalui pendekatan gaya sengketa para pihak di Kesatuan Pengelolaan Hutan Lakitan. Jurnal Analisis Kebijakan Kebutanan, 11(1), 53-64.

Gregersen, H. M., Contreras-Hermosilla, A., White, A., \& Phillips, L. (2005). Forest governance in federal systems: An overview of experiences and implications for decentralization. the politics of decentralization: forest, power and people. Indonesia: Center for International Forestry Research, Bogor. doi://10.4324/9781849773218.

Gulbrandsen, L. H. (2004). Overlapping public and private governance: can forest certification fill the gaps in the global forest regime. Global Environmental Politics, 4(2),75-99. doi.10.1162/152638004323074200.

Hendartin, E., Nugroho, B., \& Kartodihardjo, H. (2011). Institutional analysis of revolving fund loan (RFL) for the development of community forest plantations (CFP). Journal of Forestry Research, 8(2), 158-169.

Hermosilla, A.C \& Fay, C. (2005). Strengthening forest management in Indonesia through land tenure reform: Issues and framework for action. Bogor, Indonesia: Collaborating Institutions Forest Trends and World Agroforestry Center (ICRAF).

Hidayat, A. (2007). How distributional conflicts theory explain factors affecting institutional changes in coral reef governance? Lessons learned from Gili Indah Village, West Lombok Indonesia. Development, 10(2), 73-88.

Holmes A Derek. (2002). Indonesia where have all the forests gone? Washington DC: The World Bank.

Jagger, P., Luckert, M. M. K., Duchelle, A. E., Lund, J. F., \& Sunderlin, W. D. (2014). Tenure and forest income: observations from a global study on forests and poverty. World Development, 64(S1), S43-S55. doi://10.1016/j. worlddev.2014.03.004.

Kartodihardjo, H. (1998). Peningkatan kinerja pengusahaan butan alam produksi melalui kebijaksanaan penataan institusi. (Doctoral dissertation). Bogor Agricultural University, Bogor.

Kartodihardjo, H. (2008). Diskursus dan aktor dalam pembuatan dan implementasi kebijakan kehutanan: masalah kerangka pendekatan rasional. Jurnal Manajemen Hutan Tropika. XIV(1), 19-27.
Kartodihardjo, H. (2013a). Challenges for interdisciplinary use in forest management prompts of coalition of forest management, economic and institutional sciences. Jurnal Manajemen Hutan Tropika, 19(3), 208-210. doi.10.7226/jtfm.19.3.208

Kartodihardjo, H. (2013). Challenges for interdisciplinary use in forest management prompts of coalition of forest management, economic and institutional sciences. Jurnal Manajemen Hutan Tropika, 19(3), 208-210. doi://10.7226/jtfm.19.3.208.

Kartodihardjo, H. (2013b). Masalah cara pikir dan praktek kehutanan: Refleksi dan evaluasi II. In Kartodihardjo H (Ed.), Kembali ke jalan lurus: Kritik penggunaan ilmu dan praktek kebutanan. Bogor: Forci Development.

Kartodiharjo, H. (2016). Diskursus dan kebijakan institusi - politik kawasan hutan: Menelusuri studi kebijakan dan gerakan sosial sumber daya alam di Indonesia. Bogor Agricultural University, Bogor.

Koalisi Anti Mafia Hutan. (2014). Catatan kritis koalisi LSM terbadap legalitas dan kelestarian butan Indonesia: Studi independen terbadap sertifikasi SVLK. Bogor, Indonesia. KAMH.

Kesatuan Pengelolaan Hutan Produksi Meranti. (2015). Rencana pengeloaan butan jangke panjang kesatuan pengelolaan butan produksi unit iv Meranti tabun 2015-2024. Paninggalan. KPHP Meranti. (Unpublished)

Larson, A. M., \& Ribot, J. C. (2007). The poverty of forestry policy: Double standards on an uneven playing field. Sustainability Science, 2(2), 189-204. doi://10.1007/s11625-007-0030-0.

Lingkungan, P. S. dan K. (2015). Rencana strategis Direkrorat Jenderal Perbutanan Sosial dan Kemitraan Lingkungan. Jakarta.

Nurtjahjawilasa, N., Kartodihardjo, H., Nurrochmat, D. R., \& Justianto, A. (2015). The performance of forestry human resources in licensing forest utilization, the lease of forest area, and the release of forest area. Jurnal Manajemen Hutan Tropika, 21(2), 76-82. doi.10.7226/ jtfm.21.2.76.

Ostrom, E. (1990). An institution approach to the study of self-organization and selfgovernance CPR situations. In E. Ostrom (Ed.), Governing the commns: The evolution of 
istitutions for collective action (pp. 29-57). New York, Melbourne: Cambridge University Press. doi.10.2307/133271.

Ostrom, E. (2005). Doing Institutional Analysis: Digging Deeper Than Markets and Hierarchies. Handbook of New Institutional Economics, 819-848. doi://10.1007/978-3540-69305-5_31.

Ostrom, E., \& Basurto, X. (2011). Crafting analytical tools to study institutional change. Journal of Institutional Economics, 7(3),317-343. doi.10.1017/s1744137410000305.

Ostrom, E., Gardner, R., \& Walker, J. (1994). Rules, games, and common-pool resources. Michigan: The University of Michigan Press. doi://10.1017/ CBO9781107415324.004.

Ostrom, E., \& Hess, C. (2007). A framework for analyzing the knowledge commons. In C. Hess \& E. Ostrom (Eds.), Understanding knowledge as a commons (pp. 41-82). Cambridge and London: The MIT Press. doi://10.1002/ asi.

Pilgrim, S. E., Cullen, L., Smith, D., \& Pretty, J. (2007). Hidden harvest or hidden revenue A local resource use in a remote region of Southeast Sulawesi, Indonesia. Indian Journal of Traditional Knowledge, 6(1), 150-159.

Sheil, D., \& Wunder, S. (2002). The value of tropical forest to local communities: Complication caveats, and cautions. Ecology And Society, 6(2), $1-16$.

Sinabutar, P., Nugroho, B., Kartodihardjo, H., \& Darusman, D. (2015). Kepastian hukum dan pengakuan para pihak hasil pengukuhan kawasan hutan negara di Provinsi Riau. Jurnal Analisis Kebijakan Kebutanan, 12(1), 27-40.

Suhendang E. (2013). Perkembangan paradigma kehutanan. (Makalah) Diskusi pengelolaan hutan berbasis ekosistem sebagai pendekatan untuk pengelolaan hutan Indonesia dalam paradigma kehutanan Indonesia baru. Diselenggarakan dalam rangka ulang tahun emas Fakultas Kehutanan IPB (1963-2013). Bogor, Agustus 2013). Bogor.
Sunderlin, W. D., Belcher, B., Santoso, L., Angelsen, A., Burgers, P., Nasi, R., \& Wunder, S. (2005). Livelihoods, forests, and conservation in developing countries: An overview. World Development, 33(9 SPEC. ISS.), 1383-1402. doi://10.1016/j.worlddev.2004.10.004.

Suwarno, E. (2014). Analisis kelembagaan proses operasionalisasi KPH: Studi kasus KPHP Tasik. Besar Serkap di Provinsi Riau. (Doctoral dissertation). Bogor Agricultural University, Bogor.

Suwarno, E., Kartodihardjo, H., Kolopaking, L. M., \& Soedomo, S. (2015). Penggunaan konsep rules in Use Ostrom dalam analisis peraturan pembentukan organisasi Kesatuan Pengelolaan Hutan. Jurnal Analisis Kebijakan Kehutanan, 12(1), 13-27.

Tacconi, L. (2007). Illegal logging and the future of the forest. In L. (Ed. . Sayer, Jeffrey A. ( Eds) Tacconi (Ed.), Illegal logging: Law enforcement, livelihoods and the timber trade (pp. 275-290). London and Sterling, VA: Earthscan. doi://10.4324/9781849771672.

Tsujino, R., Yumoto, T., Kitamura, S., Djamaluddin, I., \& Darnaedi, D. (2016). History of forest loss and degradation in Indonesia. Land Use Policy, 57, 335-347. doi://10.1016/j. landusepol.2016.05.034.

Tucker, C.M., \& Ostrom, E. (2005). Multidisciplinary research relating institutions and forest transformations. In E. Moran, Emilio F. Ostrom (Ed.), Seeing the forest and the trees: Human-environment interactions in forest ecosystems (pp. 81-103). Michigan: MIT Press.

Tucker, C. M. (1999). Private versus common property forests: forestconditions and tenure in a honduran community. Human Ecology, 27(2), 201-230. doi://10.1023/A:1018721826964.

Wibowo, L. R., Race, D., \& Curtis, A. (2013). Communicating REDD+ issues at local level: Creating latent and manifest conflict. Indonesian Journal of Forestry Research, 10(2), 67-78. doi://10.20886/ijfr.2013.10.2.67-78. 